payments disallowed. ${ }^{59}$ Since no direct attack has been made on the lease-back device as such, some statutory change was perhaps required. But that change could have been framed so as to disallow rental deductions to the vendor-lessee, rather than to tax the rental payments to the vendee-lessor. Depreciation at the normal rate, and interest payments over the period during which the "purchase" price is repaid, would be allowed to the "lessee" as deductions." A taxable "lessor," on the other hand, would be treated as a mortgagee, and taxed only to the extent of the receipt of interest payments. After the original "lease" period, during which the loan is repaid, rental payments would be fully deductible to the lessee and fully taxable to the lessor. Since the whole transaction would be in effect treated like a mortgage rather than a sale and lease, no capital gains problem would be involved. ${ }^{61}$

This approach would be both broader and narrower than the one used. Valid business reasons for use of the lease-back device would still make that form of credit transaction useful in some situations, but the tax savings involved would be eliminated. The tax-exempt organization would lose all its advantage as vendee-lessor over taxable business, but would not be restricted in any of its unobjectionable investment habits. And another tax gimmick would be wiped off the books.

\title{
EXEMPTION OF DIVORCE SETTLEMENTS FROM ESTATE AND GIFT TAX*
}

WHEN a marriage ends in divorce, sizeable transfers from one spouse to the other are frequent. Transfers by the husband are generally designed to satisfy his continuing obligation to support his wife until he or she dies or she remarries. But, in addition, the husband may make transfers beyond his wife's support needs ${ }^{1}$ in order to secure relinquishment of dower or distributive

59. See Chicago Stoker Corp., 14 T.C. 441 (1950); Truman Bowen, 12 T.C. 446 (1949); Judson Mills, 11 T.C. 25 (1948). Cf. Clarence B. Eaton, 10 T.C. 869 (1948); Gilken Corp., 10 T.C. 445 (1948), aff'd, 176 F.2d 141 (6th Cir. 1949). The problem posed by lease-backs, of course, would be to have a lease treated as a mortgage.

60. If as is usual the normal rate of depreciation covered a longer period than the repayment of the loan, there would be a time during which the lessee was taking both rental and depreciation deductions. This was what was in fact done in the Century Electric case, supra, note 25, and seems desirable in order to compensate the lessee for disallowance of any capital loss.

61. The basis for the vendee-lessor would be the same as that for the vendor-lessee. In order to permit adjustments on this basis, the depreciation allowances given the lessee would be applied against the basis of the lessor for capital gains purposes.

* Harris v. Commissioner, 340 U.S. 106 (1950).

1. These transfers may involve extension of support payments beyond the death of the husband or wife or the remarriage of the wife, or they may be entirely separate from the support obligation. For a discussion of the extension of support payments beyond the time of the husband's death, see Note, 28 NEB. L. REv. 627 (1949). 
rights, to assure his wife's appearance in an easy divorce jurisdiction, or for a variety of other reasons. ${ }^{2}$ A similar variety of motives may induce a wife to settle property on her divorced husband even though she ordinarily has no support obligation. ${ }^{3}$ Since the husband's duty to support his wife according to his means is a normal incident of married life, and does not unduly deplete the husband's estate, its fulfillment should not be subject to gift or estate taxation. But a tax should be collected on transfers made for any other reason, because they involve property which normally would form part of the husband's taxable estate at death. ${ }^{4}$ Similarly, all transfers from the wife to the husband should be taxed.

Actually, no such logical line has been drawn. Although the estate and gift tax statutes give no express exemption for the fulfillment of a husband's support obligation, the Commissioner in 1946 ruled that all transfers made in return for release of reasonable support rights would not be subject to a transfer tax. ${ }^{5}$ But divorce settlement transfers in excess of reasonable support

2. For convenience of expression, this note will treat all transfers in connection with divorce or legal separation as made in return for a release of marital rights, although in actuality the consideration may be otherwise. The Note will subdivide marital rights into two broad categories: (a) support rights, defined as the wife's right to be supported by her husband during their joint lives or until she remarries; and (b) property rights, including dower, curtesy, statutory substitutes in the nature of dower and curtesy, and descent and distribution rights. Such a sharp division is by no means universally employed by state legislation, by court decisions, or by marital settlements made by the parties. On the contrary, the terms "support", "maintenance", and "alimony" are often used interchangeably to refer to transfers that compensate for the loss of purely support rights and of both support and property rights. Moreover, a single division of property may result in a transfer designed to settle support rights, property rights, or both. For a discussion of California's experience with fuzzy classification of divorce agreements, see Note, 2 Stan. L. Rev. 731 (1950).

This note does not discuss the problems of income tax treatment of transfers between spouses. See, e.g., INT. REv. CoDE $\$ \$ 22(\mathrm{k}) 23(\mathrm{u})$; Rudick, Marriage, Divorce and Taxes, 2 TAx L. Rev. 123 (1947); Johnson, The Alimony Tax Sections Need Overhanling, 28 TAXES 917 (1950).

3. 2 Nelson, Drorce and Annuliment $\$ 14.16$ (1945); 2 Vernter, American FaArily Laws $\$ 109$ (1932).

4. See INT. REv. CoDE $\$ 811$ (b), providing that the value of a decedent's gross estate includes the value at the time of his death of all property " $[t]$ o the extent of any interest therein of the surviving spouse, existing at the time of the decedent's death as dower, curtesy, or by virtue of a statute creating an estate in lieu of dower or curtesy." See also Learned Hand, dissenting in Meyer's Estate v. Comm'r, 110 F.2d 367, 369 (2d Cir. 1940), cert. denied, 310 U.S. 651 (1940).

5. E.T. 19, 1946-2 Cuns. Burr. 166. The Bureau justified its ruling in the following manner: "Under a decree of divorce or legal separation a husband's duty to support a divorced wife (alimony) customarily lasts only during the joint lives of the parties or until the divorced wife remarries... . The fulfillment, therefore, of this obligation by the husband merely amounts to the liquidation of a presently existing obligation, the satisfaction of which does not have the effect of diminishing or depleting the husband's estate to any greater extent than the payment of other existing legal obligations. On the other hand, a transfer to a wife under such a decree in settlement of inheritance rights is a 
needs are not uniformly taxed. Instead, taxability depends upon the form of the arrangement used to effect the settlement. Parties can formulate the amount of the transfer and the schedule of payments by entering into a binding pre-divorce agreement, by relying solely on the discretion of the divorce judge, or, combining these two devices, by submitting a recommended agreement to the divorce judge.

Under the estate and gift tax statutes as presently interpreted, only those marital settlement transfers which are based solely on an agreement between the spouses stand a good chance of being taxed. The estate tax provides that transfers "founded upon a promise or agreement" will be taxed unless made in return for "adequate and full consideration in money or money's worth." And only transfers with such a foundation must satisfy that consideration test. ${ }^{7}$ The statute goes on to specify that relinquishment of "marital rights in the decedent's property or estate" does not constitute consideration. ${ }^{8}$ Although

present transfer of what would otherwise constitute a major portion of the husband's estate on death." Id. at 168 .

The release of support rights must be incident to divorce or legal separation in order to escape a transfer tax. In actual fact, agreements involving releases of marital rights during the happy marital relationship are rare. In some states, such agreements would be void ab initio as against public policy. See Boyden, Divorce Settlement Agrecments, 39 IL.. B. J. 107, 108 (1950).

6. INT. Rev. CoDE $\$ 812$ reads as follows :

"For the purpose of the tax the value of the net estate shall be determined . . by deducting from the value of the gross estate-..

(b) Expenses, Losses, Indebtedness and Taxes.-Such amounts-

-..

(3) for claims against the estate, and

(4) for unpaid mortgages upon, or any indebtedness in respect to, property where the value of decedent's interest therein, undiminished by such mortgage or indebtedness, is included in the value of the gross estate,

as are allowed by the laws of the jurisdiction ... under which the estate is being administered. ... The deduction herein allowed in the case of claims against the estate, unpaid mortgages, or any indebtedness shall, when founded upon a promise or agreement, be limited to the extent that they were contracted bona fide and for an adequate and full consideration in money or money's worth; ....."

The legislative history of this section is traced in Merrill v. Fahs, 324 U.S. 308, 311-13 (1945).

In issuing E. T. 19, supra note 5, the Bureau stated: "It is the view of the Bureau that the surrender of support rights is not one of the 'other marital rights' referred to in the section [812(b)]." 1946-2 CuM. BuLl. 168. For a contrary view, see Adriance v. Higgins, 113 F.2d 1013 (2d Cir. 1940), and other cases cited in note 24 infra.

7. Fleming v. Yoke, 53 F. Supp. 552 (N.D.W.Va. 1944), aff'd pcr curiam, 145 F.2d 472 (4th Cir. 1944); see Comm'r v. State Street Trust Co., 128 F.2d 618 (1st Cir. 1942). See discussion in 1 Paul, Federal Estate and Gift Taxation 600-601 (1942); H.R. Rep. No. 708, 72d Cong., 1st Sess. 48 (1932) ; SEN. Rep. No. 665, 72d Cong., 1st Sess. 51. For a discussion of Congressional intent on this point, see Note, 43 ILL. L. REv. 545, 550 (1948).

8. "For the purposes of this subchapter, a relinquishment or promised relinquishment of dower, curtesy, or of a statutory estate created in lieu of dower or curtesy, or of 
the gift tax statute is less explicit, ${ }^{9}$ the Supreme Court has interpreted it to parallel estate tax treatment of marital settlements. ${ }^{10}$ Thus estate and gift taxes are likely to be imposed on divorce property settlements only if the courts find the required contractual foundation. Whenever the formulation of a property settlement is left entirely to the discretion of the divorce court, no tax is collected, as there is no underlying agreement. And even where a settlement agreement has been reached, and is submitted to a court as a basis for the divorce decree, transfers provided for in the agreement escape taxation through the application of the so-called incorporation doctrine. This doctrine holds that incorporation of a marital settlement agreement into a divorce decree by a judge with power to sanction a different arrangement renders the transfers founded upon the decree and not upon a promise or agreement.11

The validity of the incorporation doctrine reached the Supreme Court for the first time in Harris $v$. Commissioner. ${ }^{12}$ A week before entrance of their final divorce decree, Cornelia Harris and her husband negotiated a property settlement agreement in which she consented to transfer to him property worth $\$ 107,150$ more than the property he was to transfer to her. Although the agreement was to become operative only upon the entry of a final decree, it

other marital rights in the decedent's property or estate, shall not be considered to any extent a consideration 'in money or money's worth.'" INT. REv. CoDE \$ 811(b).

9. INT. REv. CODE $\S 1002$ tersely provides: "Where property is transferred for less than an adequate and full consideration in money or money's worth, then the amount by which the value of the property exceeded the value of the consideration shall, for the purpose of the tax imposed by this chapter, be deemed a gift, and shall be included in computing the amount of gifts made during the calendar year."

10. Though the gift tax was partially designed to supplement the income tax, its primary purpose was to supplement the estate tax. H.R. REP. No. 708, 72nd Cong. 1st Sess. 28; Sen. Rep. No. 665, 72d Cong. 1st Sess. 40 (1932); 2 Paul, Federal Estate and GifT Taxation 963 (1942). Therefore, in marital settlement cases, the Supreme Court has imported into the gift tax the more specific estate tax language by terming such specificity "cautious redundancy." Merrill v. Fahs, 324 U.S. 308, 312 (1945). In that case the Court held that the phrase "adequate and full consideration in money or money's worth" is to be given the same meaning in both statutes, for "to interpret the same phrases in the two taxes concerning the same subject matter in different ways where obvious reasons do not compel divergent treatment is to introduce another and needless complexity into this already irksome situation." Id. at 313.

11. Comm'r v. State Street Trust Co., 128 F.2d 618 (1st Cir. 1942) (record did "not show clearly the agreement of the parties to the decree"; nevertheless, the "decree rests on its own foundation and a contract entered into by the parties does not in any sense deprive the court of its jurisdiction to adjust the marital rights and duties of the parties"); Fleming v. Yoke, 53 F. Supp. 552 (N.D.W.Va. 1944), aff'd per curiam, 145 F.2d 472 (4th Cir. 1944) (decree "approved and adopted" the agreement between the parties); Comm'r v. Maresi, 156 F.2d 929 (2d Cir. 1946) (decree stated that "the property rights of plaintiff and defendant ... are settled and decreed in accordance with the terms and provisions of the agreement between plaintiff and defendant").

In Comm'r v. Converse, 163 F.2d 131 (2d Cir. 1947), the Second Circuit carried the incorporation doctrine from the estate tax context to the gift tax context.

12. Harris v. Comm'r, 340 U.S. 106 (1950). 
provided for enforcement regardless of any decree which might be entered. ${ }^{13}$ After perfunctory approval of the agreement by the Nevada judge, who at the time had the duty to decree an equitable settlement of both separate and community property, ${ }^{14}$ the Commissioner assessed a $\$ 28,000$ gift tax deficiency. The Tax Court, however, finding no donative intent, refused to impose a tax..$^{15}$ The Second Circuit reversed on the ground that the $\$ 107,150$ transfer was founded upon both the decree and the agreement because dual sanctions were available to enforce the agreement-contempt under the divorce decree and suit for breach of contract. ${ }^{16}$ This, the court felt, took the transfer outside the incorporation doctrine and hence made it taxable. The Supreme Court reversed the Second Circuit in a five to four decision. ${ }^{\mathbf{1 7}}$

Though Justice Douglas' majority opinion clearly held that no tax was due, how much else was decided is uncertain. The dissenting justices felt that the majority opinion turned on the fact that the agreement was not to become operative until entry of a final divorce decree. ${ }^{18}$ If this interpretation is correct, then the Harris decision goes far beyond the incorporation doctrine; a transfer could be exempt entirely from tax even though the divorce decree made no reference to the agreed-upon settlement or imposed less onerous obligations. But it seems more likely that Justice Douglas meant to apply

13. It read: "This agreement shall be submitted to the court for its approval, but nevertheless the covenants in this agreement shall survive any decree of divorce which may be entered." Brief for Respondent, p. 5. The petitioner argued: "The provision that the agreement survive the decree was plainly inserted merely for convenience in enforcing the decree ...." Brief for Petitioner, p. 62.

14. At the time of the divorce, Section 9463 of Nevada Compiled Laws read: "In granting a divorce, the court may award such alimony to the wife and shall make such disposition of the community and separate property of the parties as shall appear just and equitable ...." In 1949 the Nevada legislature removed the words "and separate." Nev. Conrp. Laws ANn. $\$ 9463$ (Supp. 1943-49).

15. Cornelia Harris, 10 T.C. 741 (1948). The Tax Court followed Estate of Barnard, 9 T.C. 61 (1947), which was subsequently reversed by the Second Circuit, Comm'r v. Barnard's Estate, 176 F.2d 233 (2d Cir. 1949). For discussion of the Tax Court's predilection for a "donative intent" test, see note 19 infra.

16. Harris v. Comm'r, 178 F.2d 861, 864-5 (2d Cir. 1949), 25 N.Y.U. L.Q. 659 (1950), 36 VA. L. REv. 106 (1950).

In Comm'r v. Barnard's Estate, 176 F.2d 233 (2d Cir. 1949), the transfer had been made before the decree was handed down. The court refused to give a retroactive effect to the incorporation. These are the only two cases in which the Second Circuit has been asked to apply the incorporation doctrine since it adopted this doctrine in the gift tax context. In both the court refused.

17. 340 U.S. 106 (1950). Chief Justice Vinson and Justices Reed, Douglas, Jackson, and Clark were in the majority. Justice Frankfurter, joined by Justices Black, Burton, and Minton, dissented.

18. "The fact that the undertakings defined by this agreement would come into force only on the occurrence of a condition, to wit, the entering of a decree of divorce, is apparently regarded as decisive of taxability." Justice Frankfurter, dissenting, $i d$. at 118. 
the orthodox incorporation doctrine, which makes tax exemption depend upon state court approval of the understanding reached by the parties. ${ }^{19}$

19. Justice Douglas stated: 'If 'the transfer' of marital rights in property is effected by the parties, it is pursuant to a 'promise or agreement' in the meaning of the statute. If 'the transfer' is effected by court decree, no 'promise or agreement' of the parties is the operative fact." Id. at 111. However, Justice Douglas did not take the trouble to specify which factor in the Harris case made the transfer "effected" by court decree.

Even assuming that under Harris the crucial factor is state court ratification of a property settlement agreement, from the majority opinion alone it is impossible to tell whether incorporation takes place when the divorce judge generally approves the agreement or when the judge specifically orders payments to be made. In his dissent, Justice Frankfurter pointed out that the divorce court approved the agreement as a whole, but specifically ordered the plaintiff to make only certain of the transfers embodied in the agreement. The divorce judge apparently made no specific reference to the agreed-upon assumption by plaintiff of $\$ 47,650$ of her husband's debts. Since the majority did not remand the case to the Commissioner for assessment of a tax on this $\$ 47,650$, general approval is apparently sufficient to invoke the incorporation doctrine.

In concluding the majority opinion, Justice Douglas suggests an alternative rationale for freeing post-marital settlements from transfer taxation. He equates marital property settlements to the dissolution of a two-partner firm. Though he admits that such agreements are not in the ordinary course of business in the conventional sense, he considers the spirit of $\S 86.8$ of Treasury Regulations 108 satisfied. This section treats transfers made in the ordinary course of business as made for adequate and full consideration in money or money's worth, if the transactions are bona fide, at arm's length, and free from any donative intent. To the extent that this 'ordinary course of business' exception has a spirit, it would seem to be donative intent.

In the field of marital transfer taxation, donative intent seems to die hard. In Comm'r v. Wemyss, 324 U.S. 303 (1945), the Supreme Court, with only Justice Roberts dissenting, rejected the concept: "Congress chose not to require an ascertainment of what too often is an elusive state of mind. For purposes of the gift tax it not only dispensed with the test of 'donative intent.' It formulated a much more workable external test, that where 'property is transferred for less than an adequate and full consideration in money or money's worth' the excess in such money value 'shall, for the purpose of the tax imposed by this title, be deemed a gift. ..." Id. at 306.

There is a strong possibility that the Tax Court will snap up Justice Douglas' suggestion as grounds for a resurgence of donative intent. In Herbert Jones, 1 T.C. 1207 (1943), the Tax Court rejected the Commissioner's plea for reference to the specific language of the estate tax when examining the adequacy of the consideration of postmarital transfers for gift tax purposes, and relied on the lack of donative intent to negate gift taxation. Despite the Supreme Court's rejection of donative intent in the Wemyss case in 1945, the Tax Court has consistently followed the Jones rationale, distinguishing the Wemyss case as involving pre-marital, as opposed to post-marital, tranfers. E.g., Edmund C. Converse, 5 T.C. 1014 (1945). The distinction has been criticized by judges of the Tax Court itself and by the Second Circuit. See, e.g., the dissent written by Judge Disney in Norman Taurog, 11 T.C. 1016, 1022 (1948); Comm'r v. Barnard's Estate, 176 F.2d 233 (2d Cir. 1949). For an exhaustive collection of recent post-nuptial transfer cases, see Note, 2 Stan. L. Rev. 321, 333 (1950) (chart). For additional discussion, see Notes, 24 IND. L. Rev. 437 (1949), 5 TAx L. Rev. 90 (1949), Murphy, Marital Settlentents and Federal Taxation, [1950] Wash. U. L. Q. 179.

The Tax Court's enthusiasm for donative intent even prior to the dictum in the majority opinion is understandable in view of the wording of the underlying statute. The problem would probably not have arisen had Congress not used the misleading 
Instead of adopting or extending the incorporation doctrine, the Supreme Court should have rejected that doctrine in toto. It is highly artificial to say that approval by a divorce judge exempts from tax an otherwise taxable transfer. ${ }^{20}$ Ordinarily the judge merely accepts any settlement which has been agreed upon by the parties, without a real inquiry into possible alternatives. ${ }^{21}$ Moreover, at least in the hands of the circuit courts, the incorporation doctrine has been applied in a quite haphazard manner. For example, a probate court decree enforcing the terms of a separation agreement does not eliminate the requirement of adequate consideration. ${ }^{22}$ Similarly, where a divorce court has incorporated into its decree an agreement to make payments to the children, those payments have been held taxable to the extent that they exceed support rights. ${ }^{23}$ The historical origin of the incorporation doctrine may explain its inconsistent application. It grew up in the pre-1946 cases involving transfers designed mainly to discharge support obligations, and was probably conceived as a makeshift device to exempt such transfers. ${ }^{24}$ In

term "gift" in drafting a statute designed to tax all inter vivos transfers made for inadequate consideration in money or money's worth.

In Comment, 48 MIICE. L. REv. 846, 851 (1950), the author recognizes the primary purpose of the gift tax is to prevent estate depletion, but argues that as a practical matter donative intent is still a useful criterion in marital settlement agreements since absent such intent extensive estate depletion is unlikely.

20. For similar criticisms of the incorporation doctrine, see 1 PaUL, Federal Estate and Gifr Taxation 610 (1942); Rudick, Marriage, Divorce and Taxes, 2 Tax L. Rev. 123, 161 (1947).

21. "Not infrequently the parties agree between themselves, in contemplation of a severance of the marital ties, what shall be done with their property and what shall be paid by the husband. The agreement is submitted to the court. The court must guard against collusion or injustice; but, if that does not appear, it will ordinarily approve the arrangement and make it part of the decree." 2 NeLsoN, Drvorce AND ANNULAENT $\$ 16.08$ (1945).

22. Markwell's Estate v. Comm'r, 112 F.2d 253 (7th Cir. 1940). As part of a divorce settlement agreement between husband and wife, the husband' agreed that upon his death their daughter should receive one-half of his estate. When the husband died the daughter sought to enforce this provision of the contract, and the probate court allowed her claim. When the husband's executor tried to deduct the amount of this transfer from the gross estate, the Seventh Circuit held that the executor had not shown that the claim was based upon adequate and full consideration.

See also Comm'r v. Greene, 41 B.T.A. 515 (1940), rez'd on other grounds, 119 F.2d 383 (9th Cir. 1941), cert. denied, 314 U.S. 641 (1941), 41 CoL. L. Rev. 1274 (1941) (payments by guardian of incompetent, out of surplus income of the incompetent's estate, to incompetent's adult children for maintenance and support, held taxable gifts, although state court had ordered guardian to make the payments).

23. Hooker v. Comm'r, 174 F.2d 863 (5th Cir. 1949); Edmund C. Converse, 5 T.C. 1014 (1945), aff'd, 163 F.2d 131 (2d Cir. 1947).

24. At first taxpayers argued that reasonable support rights were not "other marital rights in the decedent's property or estate" within the meaning of INT. REv. CODE $\S \$ 12$ (b), and that consequently the relinquishment of support rights could serve as consideration for transfer tax purposes. The courts rejected this contention. Adriance v. Higgins, 113 F.2d 1013 (2d Cir. 1940) ; Helvering v. United States Trust Co., 111 F.2d 
view of the Treasury's subsequent ruling that the release of support rights is consideration for transfer tax purposes, ${ }^{25}$ this expedient is no longer justified.

Had the Supreme Court been willing to reject the incorporation doctrine, however, troublesome problems would remain. To the extent that the Commissioner collected a tax from parties who had settled their differences by agreement, he would in effect be penalizing compromise. Furthermore, although the Commissioner would be free to look through the decree to the underlying agreement, he would face other obstacles in his attempts to curb tax-free estate depletion. Since he would still have to prove an agreement in order to levy a tax, compromise might take the form of a mere failure to argue extreme positions at the divorce hearing rather than a formal document. $^{20}$ Presumably the Commissioner could ignore decrees resulting from collusive litigation, but the obstacles to proving bad faith litigation in order to establish an underlying agreement would be administratively insurmountable. And even were a pre-divorce agreement demonstrable, the parties might successfully argue that a decree which changes the method or amount of the transfer eliminates the tax effect of the agreement. This would force the Commissioner and the courts to draw artificial lines to indicate how extensive the judicial amendment to such agreements must be in order to submerge the agreement into the decree.

Furthermore, even the most purely judge-determined transfer, clearly not founded upon an agreement, can result in estate depletion. The vast majority of American jurisdictions give divorce court judges much freedom in their awards to the less guilty spouse.27 Several states expressly authorize an immediate payment in lieu of dower rights, ${ }^{28}$ others permit the divorce judge

576 (2d Cir. 1940) ; Meyer's Estate v. Comm'r, 110 F.2d 367 (2d Cir. 1940), cert. denied, 310 U.S. 651 (1940). But in later cases courts reached a result even more favorable to taxpayers by adopting the incorporation doctrine. See cases cited in note 11 supra. Since that doctrine makes no distinction between support rights and property rights, it immunizes agreements that involve release of more than reasonable support rights.

25. See note 5 supra.

26. The written agreement might not disappear completely. The parties might feel that payment of a transfer tax was preferable to turning a state divorce judge loose on a large, complicated estate. In the Harris case the agreement was over twentyfive pages long, not an unusual length.

27. See, generally, 2 Vernier, American Fanirly Law $\$ \$ 96-111$ (1932, with 1938 Supp.).

28. Some states provide for the transfer of a fixed portion of the husband's property: ARK. Stat. AnN. \$34-1214 (1947) (wife granted divorce against husband entitled to one-third of his personal property absolutely and one-third of all realty of which the husband was seized during the marriage for her life as a bar to dower claims); ME. REv. STAT. c. 153, $\$ \$ 62,64$ (1944) (spouse not at fault receives one-third of the real estate as if the other spouse were dead); R. I. GEN. LAws c. $416 \$ \$ 5,6$ (1938) (spouse not at fault receives dower or curtesy-initiate as if the other spouse were dead; however, the wife's claim for alimony waives dower, and the husband's curtesy-initiate is subject to possible allowance to the wife).

Other states leave the settlement of property rights to the divorce court's discretion: Mirch. Srat. ANv. $\$ 25.131$ (Rice Supp. 1949) (court given duty to include in the 
to divide the parties' property equitably, ${ }^{20}$ and it is likely that courts of many other states adopt a policy of giving the more innocent spouse some reimbursement for lost property rights, even though the local statute gives the judge power to make provision for support only. ${ }^{\mathbf{3 0}}$ In each case, transfers can take place above and beyond the value of reasonable support needs, but no $\operatorname{tax}$ is collectible.

Congress should enable the Commissioner to tax every transfer incident to divorce or legal separation to the extent that the transfer exceeds the reasonable value of support rights. ${ }^{31}$ This change would free the courts and the Commissioner from the difficulty of determining when such a transfer is founded upon a promise or agreement. The amendment should permit the Commissioner to determine the reasonable value of support rights, in the absence of an acceptable allocation between release of support rights and release of property rights by the parties or the divorce court judge. ${ }^{32}$ Though it may be argued that state divorce court judges are equipped to determine support needs according to the merits of each case, the power to foreclose the Commissioner might be abused by those state courts that specialize in granting divorces.

An amendment of this sort would avoid the existing tax inequities caused by diverse court treatment of post-marital settlements and at the same time further the purpose of the estate and gift taxes.

decree a provision in lieu of dower) ; TENN. CoDE ANN. $\$ 8450$ (Williams 1934) (if wife is granted divorce, court making alimony award shall take loss of dower or distributive share into reckoning in wife's favor); W. VA. CoDE ANN. $\$ 4718$ (1949) (court shall compel compensation of innocent party for the inchoate right of dower lost by divorce).

And still other states preserve the innocent party's dower rights: Ill. Ann. STat. c. 3 $\S 173$ (1941); Mo. Rev. Stat. ANn. $\$ 1519$ (1942).

29. E.g., Iowa Code Ann. \$598.14 (1946); Ore. Comp. Laws Ann. \$9-912 (Supp. 1947) ; Wash. Rev. Stat. ANn. \$997-11 (Supp. 1949).

30. "[A] general rule for fixing the amount of alimony ... is to give the innocent wife such a sum as would leave her in as good condition as if she were the survivor on the death of her husband." 2 Nerson, Divorce AND ANNuldient $\$ 14.47$ (1945).

31. Since in some states a court has power to make the alimony provisions of a divorce decree survive the husband's death, see Note, 28 NEB. L. REV. 627, 628 (1949), the amendment should insure uniformity by defining a wife's right to support as existing only during the joint lives of the husband and wife or until the wife remarries.

32. In issuing E.T. 19, supra note 5, the Commissioner stated: "The question whether the transfer is in excess of reasonable support rights is for the determination of the Bureau. ... In making this determination the facts and circumstances of each case will be separately considered. Elements to be considered are the amount of the husband's annual income, the extent of his assets, also, the life expectancies of the parties and the probability of the wife's remarriage, alimony almost universally being limited to such periods. An agreement of the parties may provide for payments extending beyond the period of their joint lives. The required allocation in such a case will involve a determination of the question whether the aggregate amounts paid and payable exceed normal support rights, which ordinarily would terminate upon the death of the husband. The contingency of the wife's remarriage may be measured by actuarial standards." 1946-2 CuMr. Bulx. 166, 169. On the last point, see Comm'r v. Maresi, 156 F.2d 929 (2d Cir. 1946); Wolfe, Something New in Estate and Gift Taxes, 25 TAXEs 217 (1947) 